\title{
EFFECT OF CORTICOSTEROIDS ON ENDOCRINE FUNCTION IN HAEMORRHAGIC SHOCK
}

\author{
T. Oyama, A. Matsuki, T. Kudo, M. Kudo, M. Yamashita, and H. Ishihara
}

IN THIS STUDY the effect of haemorrhage on endocrine function and the anti-shock effects of methylprednisolone were investigated in dogs. Plasma concentrations of antidiuretic hormone (ADH), epinephrine, norepinephrine, aldosterone and cortisol were measured simultaneously during and following haemorrhagic hypotension. Other parameters such as urine volume and osmolality, serum and urine electrolytes and blood glucose were also determined simultaneously during the procedure.

\section{Materials AND Method}

Thirty-two mongrel dogs weighing seven to ten kilograms were divided into four equal groups of eight dogs each: (1) group one: not treated with steroids and subjected to haemorrhagic shock twice; (2) group two: not treated with steroids and subjected to haemorrhagic shock once; (3) group three: dogs receiving methylprednisolone $15 \mathrm{mg} / \mathrm{kg}$ body weight; (4) group four: dogs with methylprednisolone $30 \mathrm{mg} / \mathrm{kg}$.

Dogs of all four groups were anaesthetized with intravenous pentobarbitone $30 \mathrm{mg} / \mathrm{kg}$ body weight, followed by tracheal intubation. Ventilation was controlled with an AIKA ventilator on room air, set at a tidal volume of $15 \mathrm{ml} / \mathrm{kg}$ body weight and a respiratory rate 12 per minute to maintain $\mathrm{PaCO}_{2}$ at 35 to $40 \mathrm{~mm} \mathrm{Hg}$. A catheter was inserted into the right femoral artery to measure arterial blood pressure, to permit controlled bleeding and blood sampling. The left femoral vein was used for administration of fluids and drugs.

After obtaining the control blood sample, each animal was bled three times over a period of 30 minutes to the extent of $11 \mathrm{ml} / \mathrm{kg}$ body weight of arterial blood, including the blood samples, until the final mean arterial blood pressure had decreased to around $50 \mathrm{~mm} \mathrm{Hg}$. It was kept there for

T. Oyama, M.D., Professor of Anesthesiology; A. Matsuki, M.D., Associate Professor of Anesthesiology; T. Kudo, M.D., M. Kudo. B.S., M. Yamashita, M.D., H. Ishihara, M.D. Fellows of Department of Anesthesiology, Hirosaki University Medical School, Hirosaki, Aomori-ken, Japan.
15 minutes for group one animals or for $30 \mathrm{~min}$ utes for groups two, three and four. Thirty minutes after recovery from hypotension with infusion twice of blood $5 \mathrm{ml} / \mathrm{kg}$ and of hydroethyl starch $5 \mathrm{ml} / \mathrm{kg}$ over a period of 15 minutes, animals in group one were bled again until the mean arterial pressure had reached $50 \mathrm{~mm} \mathrm{Hg}$ for 15 minutes. For groups two, three and four there was no second hypotension, and both hydroethyl starch $5 \mathrm{ml} / \mathrm{kg} / 15 \mathrm{~min}$ and blood $5 \mathrm{ml} / \mathrm{kg} / 15 \mathrm{~min}$ were given twice at 30 minutes and 45 minutes each after the mean arterial pressure had fallen to $50 \mathrm{~mm} \mathrm{Hg}$. Methylprednisolone $15 \mathrm{mg} / \mathrm{kg}$ or 30 $\mathrm{mg} / \mathrm{kg}$ body weight was administered intravenously just prior to the infusion of these fluids to group three and four animals.

Measurements were made at the following times: (1) control, before haemorrhage and every 15 minutes thereafter eight times during the procedure for group one. (2) control, before haemorrhage; then 15 minutes after the mean arterial pressure had reached $50 \mathrm{~mm} \mathrm{Hg}$; 15 minutes after the start of infusion of hydroethyl starch and blood; thereafter twice for groups two, three and four as shown in Figures 1 and 2.

ADH was measured on $2 \mathrm{ml}$ of plasma by the method of Kudo, et al.' by radioimmunoassay employing anti-lysin-vasopressin of Inolex Co. Ltd. as an anti-serum, ${ }^{125} \mathrm{I}$-arginine-vasopressin as labeled hormone, and arginine-8-vasopressin of Sandoz Pharmaceutical Co. Ltd. as a standard. Recovery rate was 73.9 per cent, coefficient of variation of the same sample was 11 per cent. The minimum detecting range by our method was $1 \mu \mathrm{U} /$ tube, which indicates good reliability of the method. Catecholamine concentration was determined on $10 \mathrm{ml}$ of plasma according to the method of Griffiths, et al. ${ }^{2}$ using trihydroxyindol with spectrofluorimetry. The recovery rate for epinephrine was 67.0 per cent, coefficient of variation was 10.8 per cent, minimum detecting range was $0.2 \mathrm{ng}$. The corresponding figures for norepinephrine were 65.4 per cent, seven per cent and $0.1 \mathrm{ng}$.

Aldosterone concentration was measured on $0.5 \mathrm{ml}$ of plasma by using ${ }^{3} \mathrm{H}$-aldosterone and aldosterone anti-serum according to the method 


\section{Procedure of Experiment (1)}

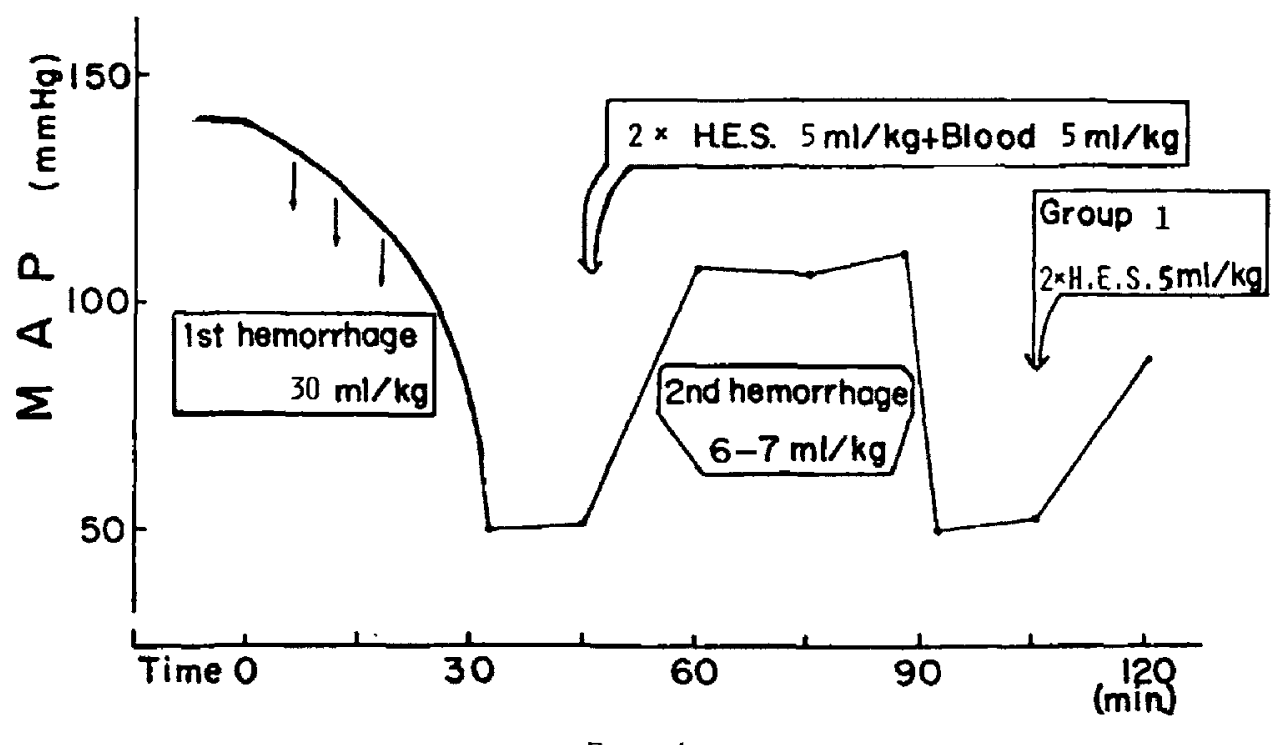

FIGURE I

\section{Procedure of Experiment (2)}

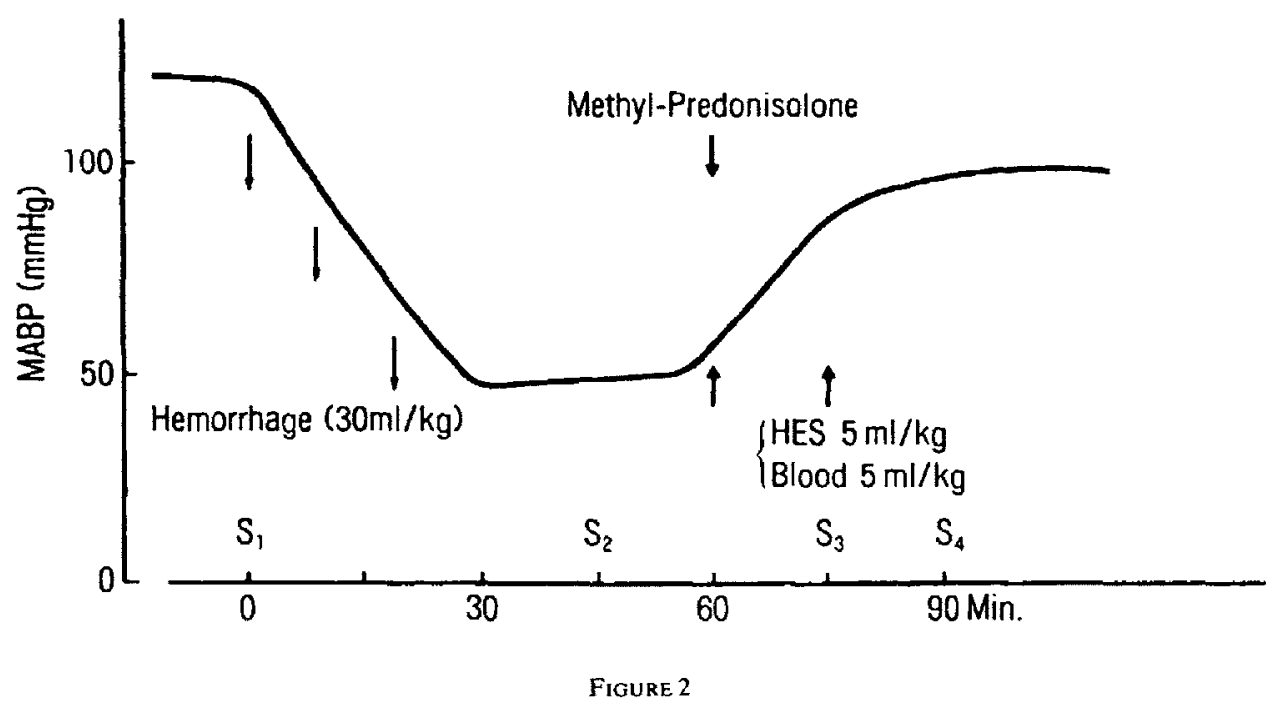




\section{Effect of Hemorrhage on Plasma Levels of ADH \& Catecholamines}

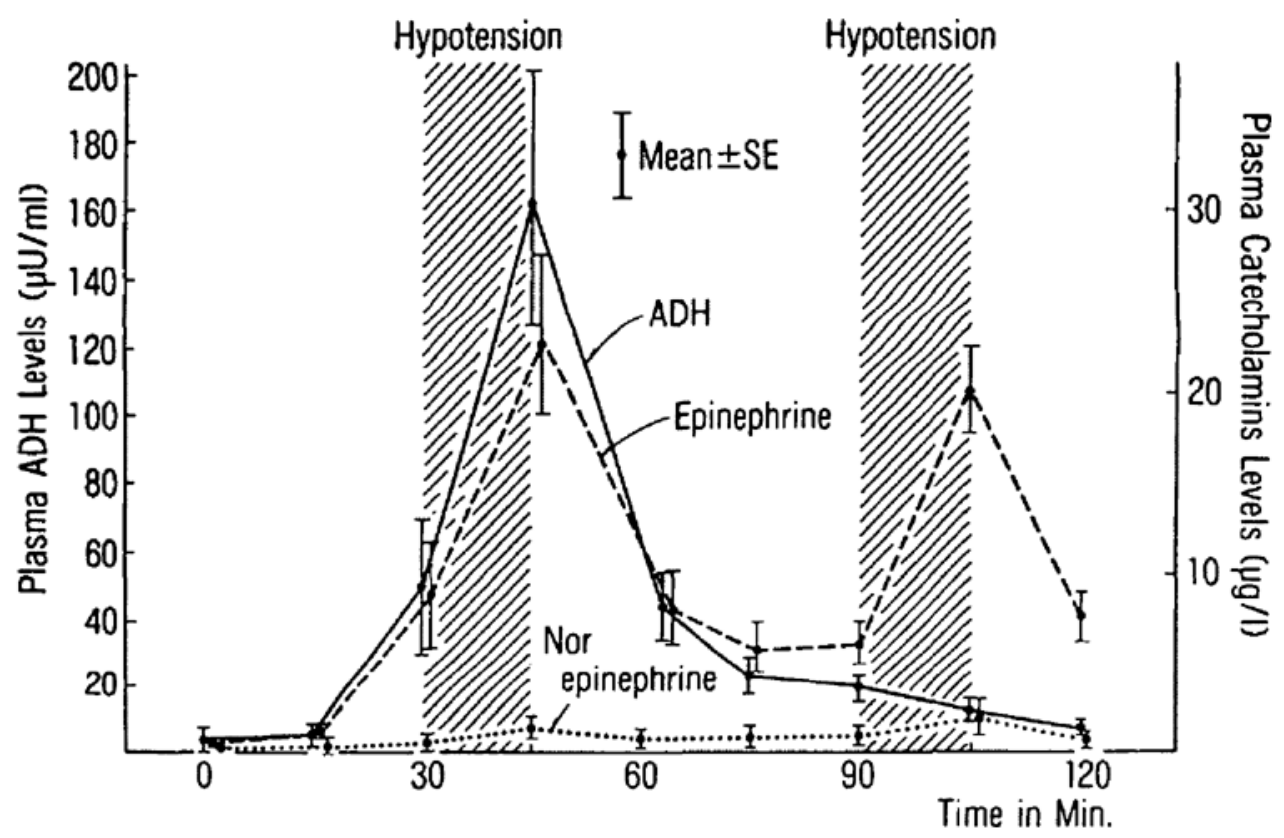

Figure 3

of Mackenzie ${ }^{3}$ by means of a Beckman liquid scintillation counter. The recovery rate was 85 per cent, coefficient of variation was nine percent, and the minimum range of sensitivity was $1 \mathrm{pg}$. Plasma cortisol levels were determined in $0.5 \mathrm{mi}$ of plasma according to the method of Rudd, et al. ${ }^{4}$ The recovery rate was 100 per cent, coefficient of variation was 1.5 per cent and the minimum range of sensitivity was $5 \mathrm{ng}$. Plasma concentrations of these hormones before haemorrhage was expressed as 100 per cent, and the correction was made for haematocrit value. Student's t-test was used for the statistical analysis.

\section{RESULTS}

\section{Plasma ADH}

Plasma ADH levels increased 50 times over control values on the first hypotension, but no appreciable further increase was evident on the second hypotension in group one animals (Figure 3). In groups two, three and four, plasma ADH levels rose 17 to 43 fold compared with controls 15 minutes after mean arterial pressure had fallen to $50 \mathrm{~mm} \mathrm{Hg}$ as shown in Table I. They decreased gradually following the administration of blood and fluid, although they still remained significantly higher than the control values. Following the administration of methylprednisolone 15 $\mathrm{mg} / \mathrm{kg}$ and $30 \mathrm{mg} / \mathrm{kg}$ plasma ADH concentrations decreased markedly to almost pre-shock control levels as shown in Table II and Figure 4. For instance, in the control group plasma ADH was still five times that of the pre-shock period. The corresponding figures were 0.9 times in group three and 1.3 times in group four. In group four, the difference was statistically significant.

\section{Plasma epinephrine and norepinephrine}

In group one, plasma epinephrine concentrations increased significantly to 35 and 40 times control level during the first and second hypotension respectively (Figure 3). In groups two, three and four, plasma epinephrine increased significantly during the shock period in all the groups, similar to the first hypotension in group one. It was still significantly higher than controls even after the administration of blood and fluid. For instance, in the control group the plasma epinephrine level was still ten times as high as the 


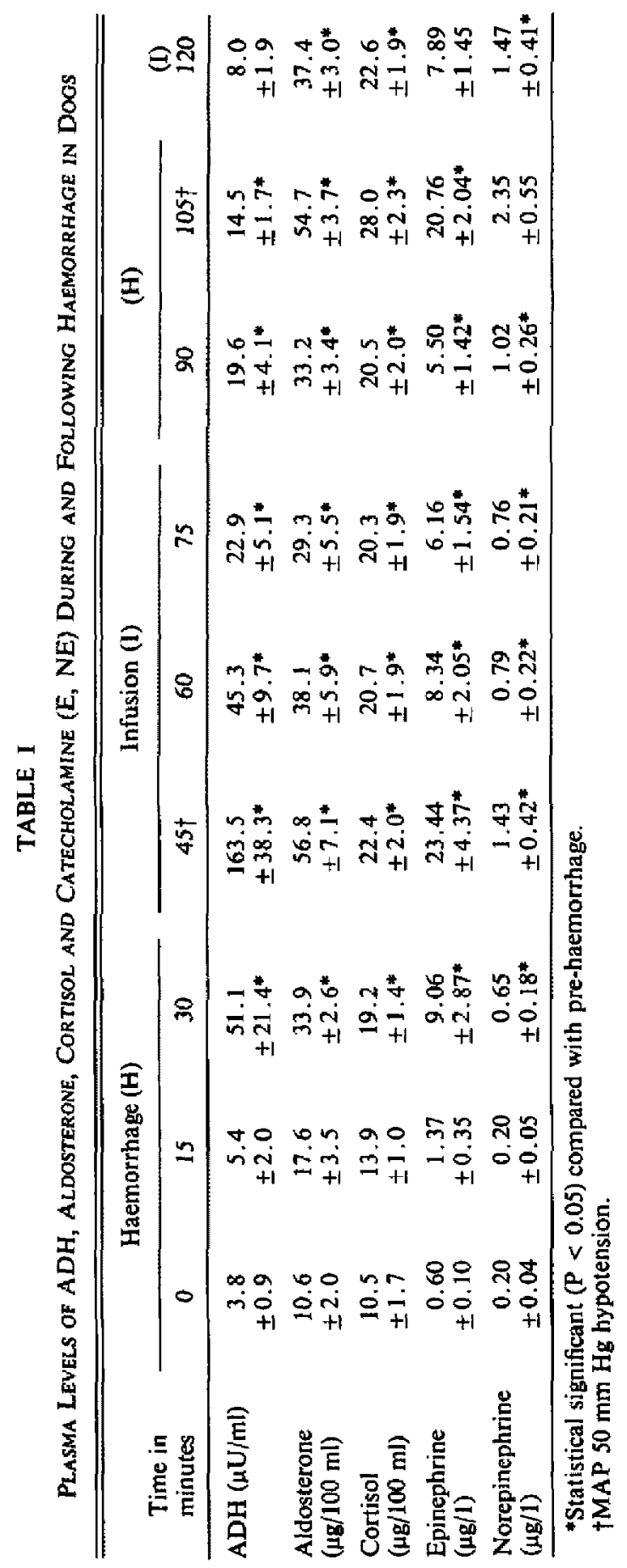


TABLE II

Effects of Methyl-prednisolone on Plasma ADH, CA and Cortisol Concentrations During HaemorRHAGIC SHOCK IN DOGS

\begin{tabular}{|c|c|c|c|c|c|c|}
\hline Hormone & & Pre-shock & Shock 15 minutes & $\begin{array}{l}15 \text { minutes after } \\
\text { reinfusion }\end{array}$ & $\begin{array}{l}30 \text { minutes after } \\
\text { reinfusion }\end{array}$ & $\begin{array}{c}45 \text { minutes } \\
\text { after } \\
\text { reinfusion }\end{array}$ \\
\hline $\mathrm{ADH}(\mu \mathrm{u} / \mathrm{ml})$ & $\begin{array}{l}\text { Control } \\
\text { MP-15 } \\
\text { MP-30 }\end{array}$ & $\begin{array}{l}3.8 \pm 0.9 \\
4.3 \pm 1.7 \\
3.4 \pm 0.6\end{array}$ & $\begin{array}{r}163.5 \pm 38.3^{*} \\
73.3 \pm 13.8^{*} \\
82.6 \pm 13.2^{*}\end{array}$ & $\begin{array}{c}45.3 \pm 9.7^{*} \\
5.2 \pm 0.7^{*} \\
5.0 \pm 1.6\end{array}$ & $\begin{array}{c}22.9 \pm 5.1^{*} \\
4.1 \pm 0.7 \\
4.7 \pm 0.7\end{array}$ & $\begin{array}{c}19.6 \pm 4.1^{*} \\
5.1 \pm 0.9 \\
6.5 \pm 1.7\end{array}$ \\
\hline $\begin{array}{l}\text { Epinephrine } \\
(\mu \mathrm{g} / \mathrm{L})\end{array}$ & $\begin{array}{l}\text { Control } \\
\text { MP-15 } \\
\text { MP-30 }\end{array}$ & $\begin{array}{l}0.60 \pm 0.10 \\
1.02 \pm 0.28 \\
0.84 \pm 0.13\end{array}$ & $\begin{array}{l}23.44 \pm 4.37^{*} \\
20.22 \pm 5.23^{*} \\
24.65 \pm 6.29^{*}\end{array}$ & $\begin{array}{l}8.34 \pm 2.05^{*} \\
6.71 \pm 2.96 \\
7.63 \pm 3.09\end{array}$ & $\begin{array}{l}6.16 \pm 1.54^{*} \\
2.41 \pm 0.79 \\
2.62 \pm 0.77^{*}\end{array}$ & $\begin{array}{l}6.49 \pm 1.42^{*} \\
2.72 \pm 1.09 \\
3.73 \pm 1.64\end{array}$ \\
\hline $\begin{array}{l}\text { Norepinephrine } \\
(\mu \mathrm{g} / \mathrm{L})\end{array}$ & $\begin{array}{l}\text { Control } \\
\text { MP-15 } \\
\text { MP-30 }\end{array}$ & $\begin{array}{l}0.20 \pm 0.04 \\
0.36 \pm 0.08 \\
0.39 \pm 0.08\end{array}$ & $\begin{array}{l}1.43 \pm 0.42^{*} \\
1.74 \pm 0.58^{*} \\
2.61 \pm 0.82^{*}\end{array}$ & $\begin{array}{l}0.79 \pm 0.22^{*} \\
0.64 \pm 0.21 \\
1.66 \pm 0.75\end{array}$ & $\begin{array}{l}0.76 \pm 0.21^{*} \\
0.54 \pm 0.19 \\
0.88 \pm 0.23^{*}\end{array}$ & $\begin{array}{l}1.02 \pm 0.26^{*} \\
0.82 \pm 0.27 \\
0.98 \pm 0.30\end{array}$ \\
\hline $\begin{array}{l}\text { Cortisol } \\
(\mu \mathrm{g} / 100 \mathrm{ml})\end{array}$ & $\begin{array}{l}\text { Control } \\
\text { MP-15 } \\
\text { MP-30 }\end{array}$ & $\begin{array}{l}10.5 \pm 1.7 \\
16.5 \pm 1.7 \\
13.0 \pm 0.8\end{array}$ & $\begin{array}{l}22.4 \pm 2.0^{*} \\
24.9 \pm 1.8^{*} \\
23.6 \pm 1.5^{*}\end{array}$ & $\begin{array}{l}20.7 \pm 1.9^{*} \\
28.4 \pm 2.8^{*} \\
27.2 \pm 1.4^{*}\end{array}$ & $\begin{array}{l}20.3 \pm 1.9^{*} \\
27.3 \pm 2.0^{*} \\
23.7 \pm 1.3^{*}\end{array}$ & $\begin{array}{l}20.5 \pm 2.0^{*} \\
27.2 \pm 3.6^{*} \\
24.3 \pm 1.6^{*}\end{array}$ \\
\hline
\end{tabular}

Each group consisted of eight dogs.

* Statistically significant as compared with pre-shock value.

Each figure denotes mean $\pm \mathrm{SE}$.

Reinfusion denotes $5 \mathrm{ml} / \mathrm{kg}$ of hydroxy-ethyl starch and $5 \mathrm{ml} / \mathrm{kg}$ of blood.

\section{Effect of Methyl-predonisolone on Plasma Levels of ADH in Posthemorrhagic Hypotension in Dogs}

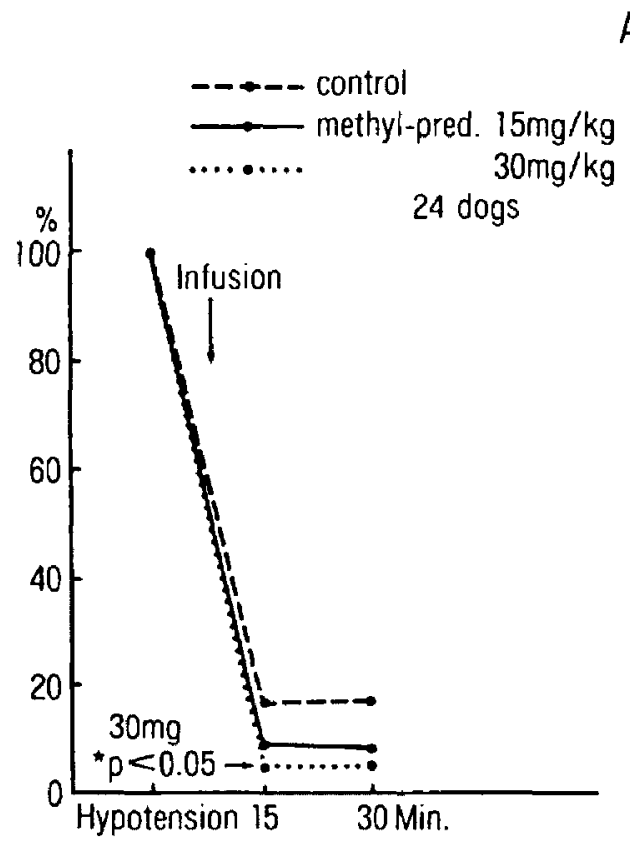

$\mathrm{ADH}$

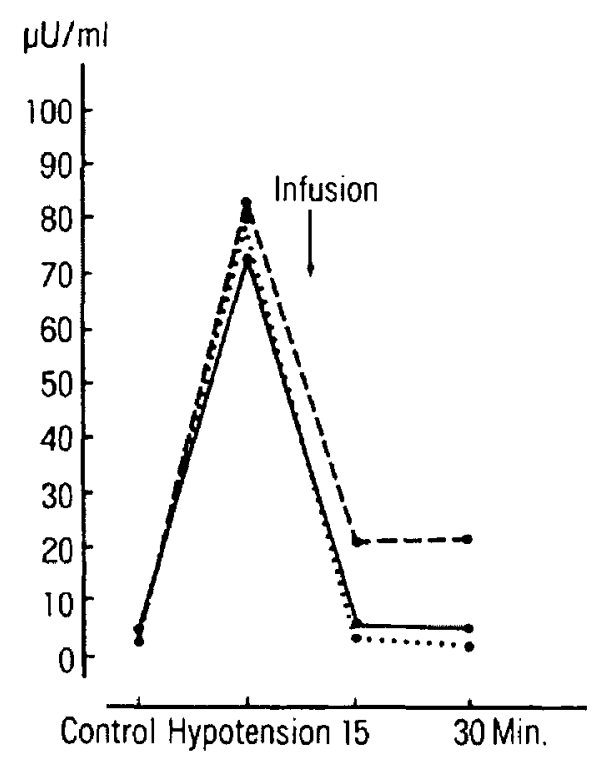


Effect of Methyl-predonisolone on Plasma Levels of Adrenalin in Posthemorrhagic Hypotension in Dogs

Adrenalin
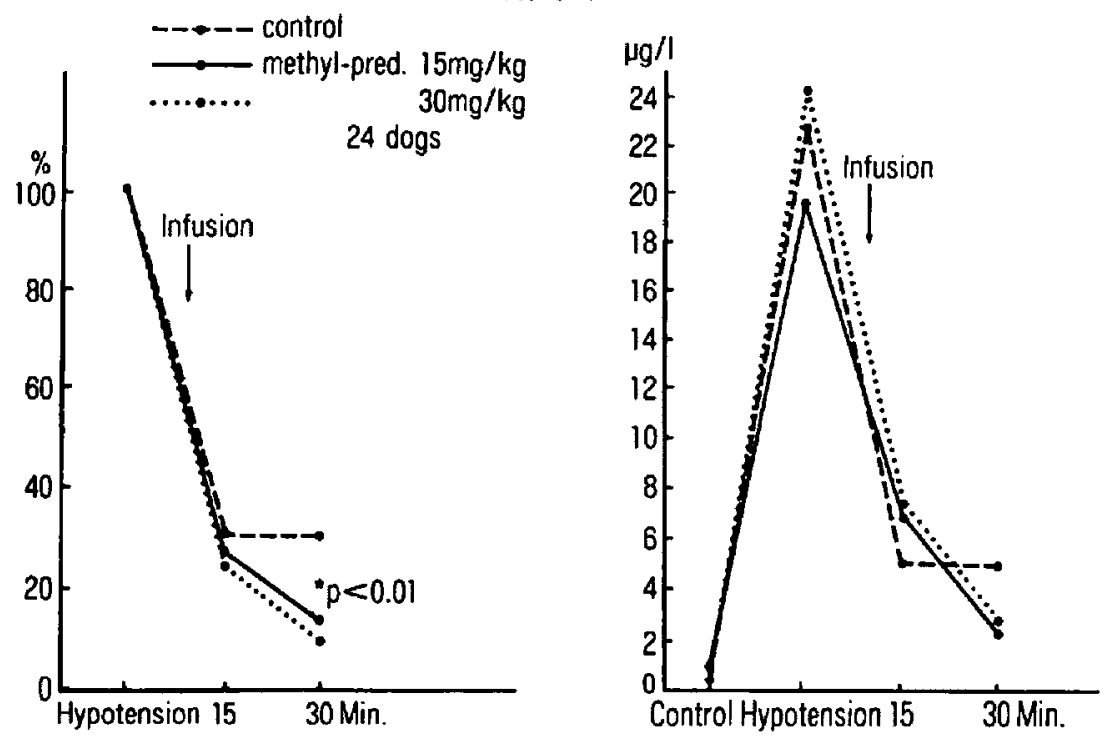

FIGURE 5

\section{Effect of Hemorrhage on Plasma Levels of Aldosterone \& Cortisol}

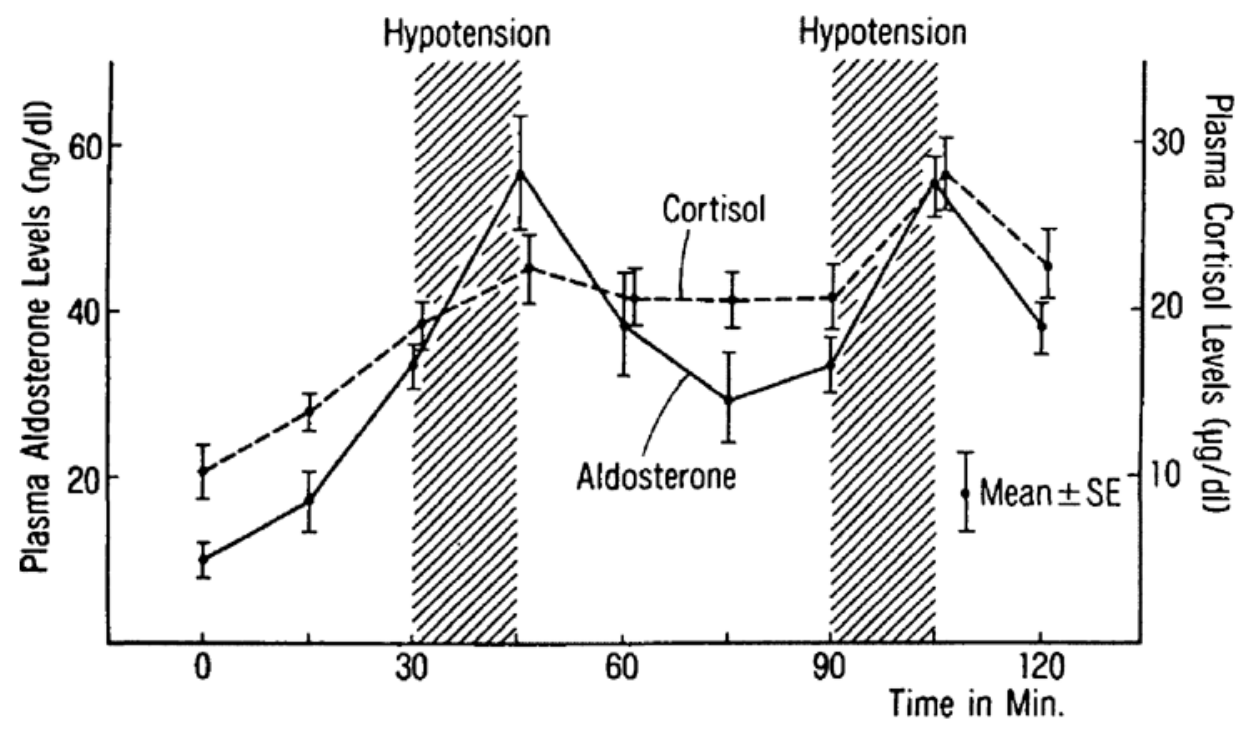

Figure 6 


\section{Effect of Methyl-predonisolone on Plasma Levels of Aldosterone in Posthemorrhagic Hypotension in Dogs}
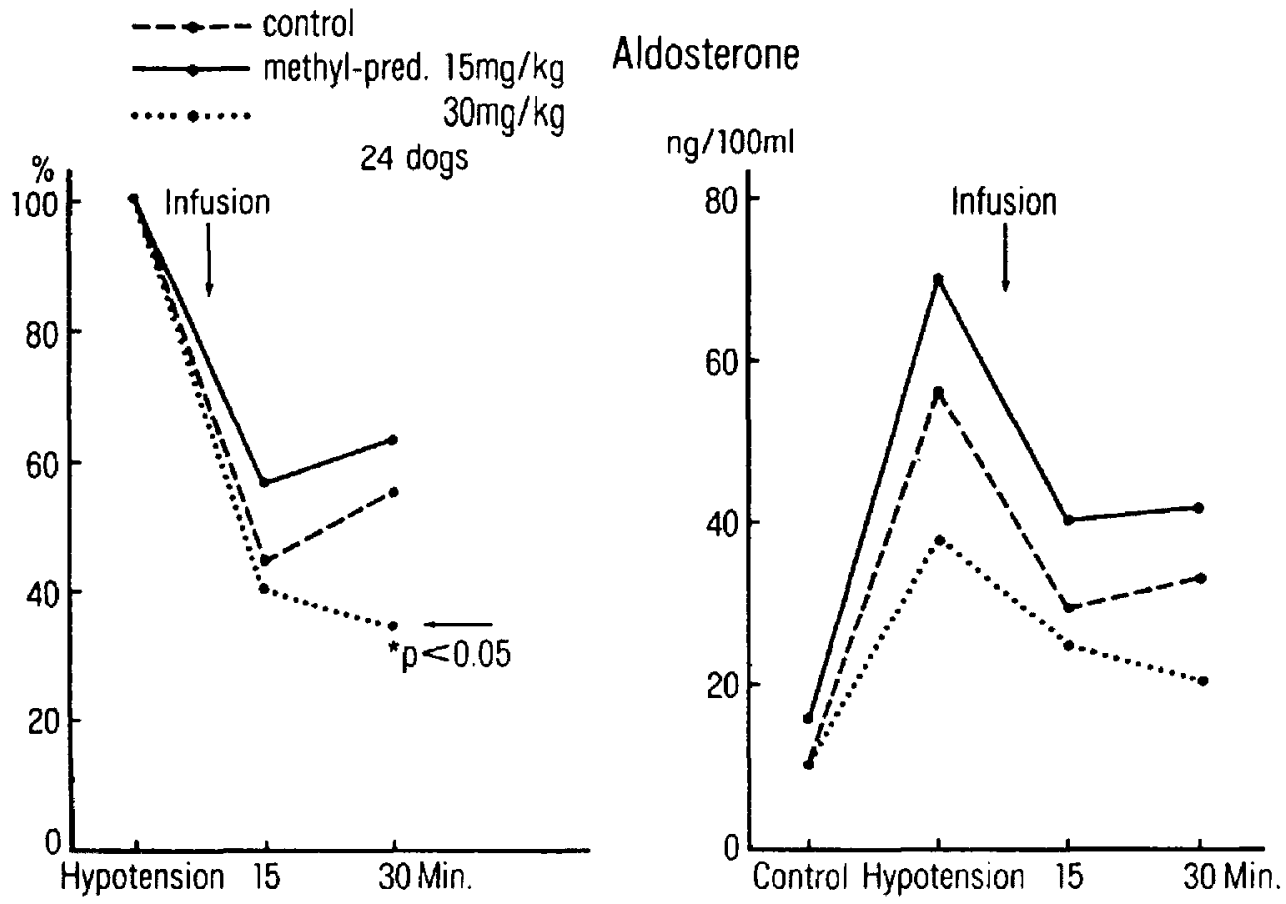

FIGURE 7

pre-shock control level. The corresponding figures in groups three and four were 2.3 times and 3.1 times respectively. There was a statistically significant difference in the methylprednisolone $30 \mathrm{mg}$ group four (Table II, Figure 5). Plasma norepinephrine levels showed a seven times increase during the first hypotension and a ten times increase during the second in group one. However, they did not exceed $2.5 \mu \mathrm{g} / 1$ (Table I). A trend of plasma norepinephrine concentration similar to that in group one was observed to occur in the remaining three groups in response to the first hypotension. (Table II).

\section{Plasma cortisol and aldosterone}

Plasma cortisol levels increased significantly with shock in all four groups. Plasma aldosterone levels increased five times control values with both the first and second hypotension in group one (Table I, Figure 6). In groups two, three and four a similar increase (2.9 to 5.4 times) was observed following haemorrhage. Administration of methylprednisolone significantly decreased the plasma concentrations of aldosterone; indeed, they were lower than those of the control group not treated with steroid (Figure 7). For instance, plasma aldosterone levels 30 minutes after recovery from hypotension were 3.2 times, 2.5 times and 1.4 times as high as the pre-shock control levels in each of groups two, three and four. In this post-hypotensive period, a statistically significant difference from control level was found in group four (Figure 7).

\section{Urine volume and osmolality}

Urine output decreased markedly during shock, but it recovered to 50 per cent of the pre-shock level after the infusion of blood and fluid in groups one and two. However, in groups three and four, in which methylprednisolone 15 $\mathrm{mg} / \mathrm{kg}$ and $30 \mathrm{mg} / \mathrm{kg}$ were administered, the urine output had increased to 84 per cent and 149 per 


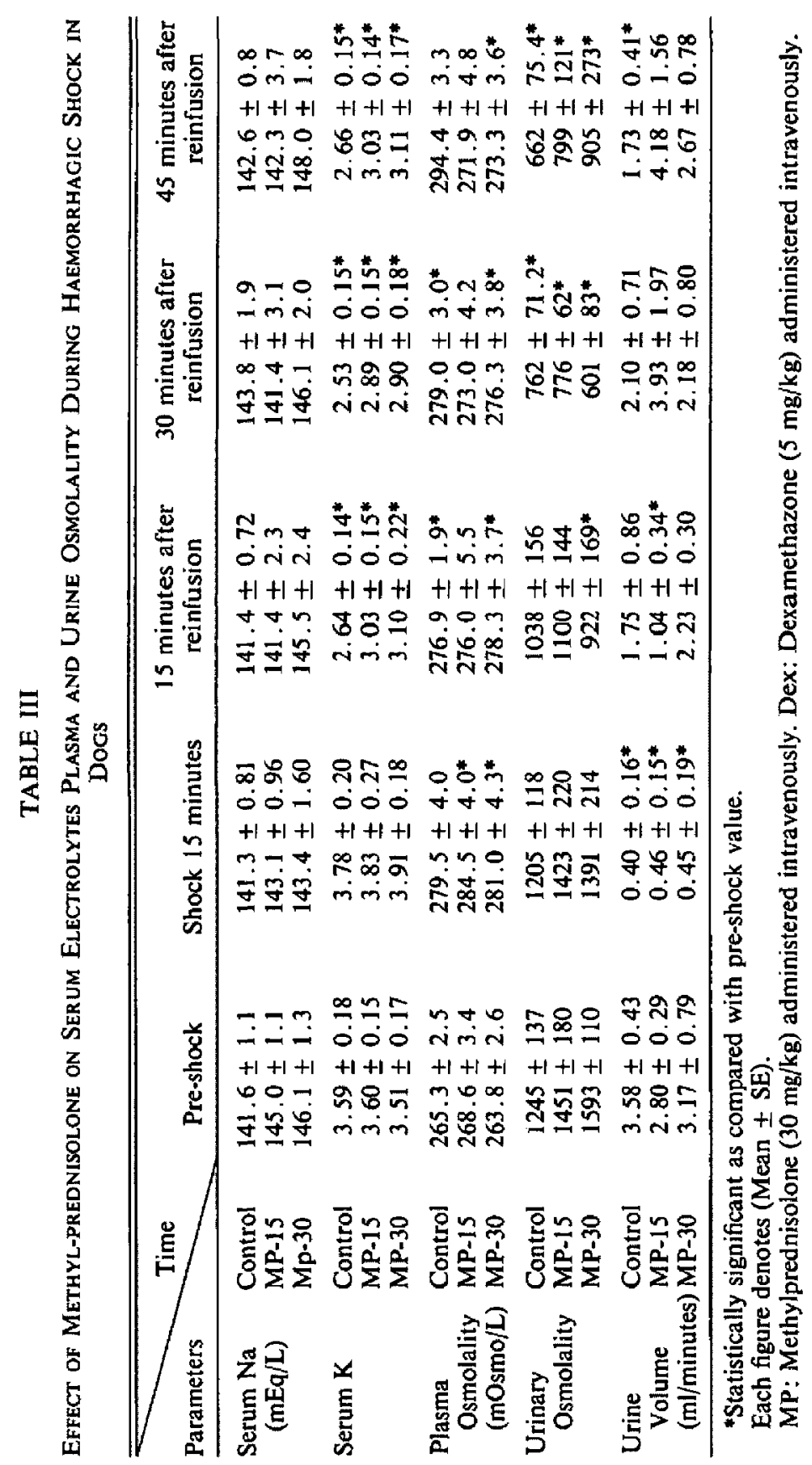


TABLE IV

Effect of Methyl-prednisolone on Acid-base Balance During Haemorrhagic Shock in Dogs

\begin{tabular}{|c|c|c|c|c|c|c|}
\hline Parameters & & Pre-shock & $\begin{array}{c}\text { Shock } \\
15 \text { minutes }\end{array}$ & $\begin{array}{l}15 \text { minutes after } \\
\text { reinfusion }\end{array}$ & $\begin{array}{l}30 \text { minutes after } \\
\text { reinfusion }\end{array}$ & $\begin{array}{l}45 \text { minutes after } \\
\text { reinfusion }\end{array}$ \\
\hline $\mathrm{pH}$ & $\begin{array}{l}\text { Control } \\
\text { MP-15 } \\
\text { MP-30 }\end{array}$ & $\begin{array}{l}7.47 \pm 0.01 \\
7.38 \pm 0.02 \\
7.38 \pm 0.01\end{array}$ & $\begin{array}{l}7.41 \pm 0.02 \\
7.33 \pm 0.02 \\
7.35 \pm 0.02 *\end{array}$ & $\begin{array}{l}7.36 \pm 0.02^{*} \\
7.31 \pm 0.03 \\
7.28 \pm 0.01\end{array}$ & $\begin{array}{l}7.36 \pm 0.02^{*} \\
7.33 \pm 0.04 \\
7.31 \pm 0.02 *\end{array}$ & $\begin{array}{l}7.38 \pm 0.02^{*} \\
7.36 \pm 0.03 \\
7.31 \pm 0.02\end{array}$ \\
\hline $\begin{array}{l}\mathrm{PaO}_{2} \\
(\mathrm{~mm} \mathrm{Hg})\end{array}$ & $\begin{array}{l}\text { Control } \\
\text { MP-15 } \\
\text { MP-30 }\end{array}$ & $\begin{array}{r}100.4 \pm 4.0 \\
94.8 \pm 3.4 \\
95.9 \pm 2.6\end{array}$ & $\begin{array}{c}103.6 \pm 4.9 \\
99.8 \pm 3.8 \\
107.5 \pm 3.9^{*}\end{array}$ & $\begin{array}{l}106.5 \pm 5.5 \\
106.8 \pm 2.6^{*} \\
110.9 \pm 3.7^{*}\end{array}$ & $\begin{array}{l}108.0 \pm 5.2 \\
112.0 \pm 2.8^{*} \\
112.9 \pm 6.1\end{array}$ & $\begin{array}{l}110.6 \pm 6.2 \\
111.1 \pm 2.9 \\
111.9 \pm 4.2^{*}\end{array}$ \\
\hline $\begin{array}{l}\mathrm{Pa}_{\mathrm{co} 2} \\
\quad(\mathrm{~mm} \mathrm{Hg})\end{array}$ & $\begin{array}{l}\text { Control } \\
\text { MP-15 } \\
\text { MP-30 }\end{array}$ & $\begin{array}{l}27.5 \pm 0.5 \\
38.5 \pm 1.5 \\
37.4 \pm 1.3\end{array}$ & $\begin{array}{l}24.4 \pm 1.1^{*} \\
31.3 \pm 1.3^{*} \\
28.9 \pm 2.0^{*}\end{array}$ & $\begin{array}{l}27.3 \pm 0.9 \\
35.0 \pm 1.8 \\
35.9 \pm 1.8\end{array}$ & $\begin{array}{l}28.0 \pm 0.8 \\
35.1 \pm 2.2 \\
38.4 \pm 1.2\end{array}$ & $\begin{array}{l}27.5 \pm 0.7 \\
32.8 \pm 1.7^{*} \\
36.4 \pm 2.3\end{array}$ \\
\hline$\frac{\mathrm{BE}}{(\mathrm{mEq} / \mathrm{L})}$ & $\begin{array}{l}\text { Control } \\
\text { MP-15 } \\
\text { MP-30 }\end{array}$ & $\begin{array}{l}-2.3 \pm 0.5 \\
-2.6 \pm 1.0 \\
-2.5 \pm 0.5\end{array}$ & $\begin{array}{l}-7.7 \pm 1.0^{*} \\
-8.5 \pm 0.9^{*} \\
-9.6 \pm 0.9^{*}\end{array}$ & $\begin{array}{l}-8.6 \pm 1.1^{*} \\
-8.0 \pm 1.5^{*} \\
-9.5 \pm 0.9^{*}\end{array}$ & $\begin{array}{l}-7.6 \pm 1.4^{*} \\
-6.4 \pm 1.8 \\
-6.5 \pm 1.0^{*}\end{array}$ & $\begin{array}{l}-7.1 \pm 1.2^{*} \\
-7.4 \pm 2.4 \\
-7.4 \pm 1.0^{*}\end{array}$ \\
\hline $\mathrm{Ht}(\%)$ & $\begin{array}{l}\text { Control } \\
\text { MP-15 } \\
\text { MP-30 }\end{array}$ & $\begin{array}{l}36.6 \pm 1.9 \\
36.9 \pm 1.9 \\
36.1 \pm 1.7\end{array}$ & $\begin{array}{l}34.1 \pm 1.9 \\
36.3 \pm 1.9 \\
38.5 \pm 2.0\end{array}$ & $\begin{array}{l}31.9 \pm 2.0 \\
34.3 \pm 2.4 \\
36.3 \pm 2.1\end{array}$ & $\begin{array}{l}30.4 \pm 2.1 \\
32.4 \pm 2.5 \\
33.0 \pm 2.1\end{array}$ & $\begin{array}{l}29.9 \pm 2.1 \\
32.9 \pm 2.2 \\
33.1 \pm 2.0\end{array}$ \\
\hline
\end{tabular}

Each group consisted of eight dogs.

*Statistically significant as compared with pre-shock value. Each figure denotes mean \pm SE. Reinfusion denotes $5 \mathrm{ml} / \mathrm{kg}$ of hydroxy-ethyl starch and $5 \mathrm{ml} / \mathrm{kg}$ of blood.

BE: base excess.

cent respectively of the pre-shock levels, $45 \mathrm{~min}$ utes after fluid infusion (Table II). Urine osmolality decreased significantly in all four groups following fluid infusion. Plasma osmolality increased during shock and decreased following fluid infusion (Table III).

\section{Blood gases and $p H$}

Blood $\mathrm{pH}$ decreased following haemorrhagic shock in all the groups, although there was no significant difference among them. $\mathrm{Pa}_{2}$ increased significantly following the administration of methylprednisolone in groups three and four, but there was no increase in groups one and two (Table IV).

\section{Discussion}

Plasma ADH levels increased acutely and markedly during haemorrhagic shock. The stimulation of hypothalamic osmoreceptors and carotid baroreceptors due to the blood loss and hypotension induce secretion of ADH from the posterior pituitary. The marked elevation of plasma ADH concentration, as much as 17 - to 43 -fold compared with pre-shock level, provokes not only preservation of extracellular fluid but also peripheral vaso-constriction. Administration of methylprednisolone accelerated the return of plasma ADH concentration toward pre-shock level compared with infusion only. This effect was substantiated by the increased urine output compared with that of the control group. Therefore, the administration of adrenocortical steroids during haemorrhagic shock might exert a beneficial effect through the reduction of plasma ADH levels.

Aldosterone enhances sodium and chloride reabsorption and increases secretion of potassium and hydrogen ions into the tubular lumen in the distal portions of the nephron. Thus, indirectly, aldosterone promotes the renal tubular reabsorption of water and so conserves the intravascular volume as one of the defense mechanisms against stress. However, excessive secretion of aldosterone could induce oedema and hypertension. Therefore, the lowered aldosterone secretion induced by steroid might contribute to increased urine output.

The relation between the secretion of ADH and that of norepinephrine is controversial. Shimamoto and Miyahara ${ }^{5}$ reported a degressing effect of norepinephrine on the ADH secretion in man, while Sachs, et al. ${ }^{6}$ failed to find any definite relationship. In our study, plasma levels of both ADH and norephinephrine rose with the first shock, but in the second shock only norephinephrine increased. These findings would imply 
that an antagonistic effect of norephinephrine on $\mathrm{ADH}$ secretion is doubtful. It would rather suggest a limited reservoir of ADH in the posterior pituitary. Therefore, in response to an emergency situation such as acute haemorrhage, ${ }^{6}$ if $\mathrm{ADH}$ had already been exhausted in the first shock, little would be available to be secreted with the second shock.

The increased plasma levels of cortisol and catecholamine during and following haemorrhagic shock contribute to the tendency to metabolic acidosis. Factors contributing to the reduced urine output during shock are postulated to be the reduction of cardiac output and of renal blood flow and increased secretion of $\mathrm{ADH}$ and aldosterone. Plasma osmolality correlated well with plasma ADH concentration during the shock.

The mechanism of the shock-protecting effect of steroids is not clearly known, although several theories have been advanced. ${ }^{7-9}$ The vasodilator action of steroids has been postulated to be related to the alpha-adrenergic receptor blockade. ${ }^{7}$ Non-specific inhibition of the actions of various vasoconstricting agents released into the blood in shock has also been postulated. ${ }^{9}$ It has been suggested that steroids inhibit the local inactivation process of catecholamines, by which they potentiate the sympathomimetic actions of norepinephrine. ${ }^{10,}, 11$

The magnitude of increase of norepinephrine was less than that of epinephrine during shock in our study, and this agrees with the report by Perry, et al. ${ }^{12}$ The fact that the adrenal content of norepinephrine is one quarter of epinephrine in the dog might account for this finding. Despite the short half life of epinephrine of about 25 seconds, its plasma concentration, determined every 15 minutes, was still high after transfusion. This would suggest the continuous over-secretion of epinephrine from the adrenal medulla even after recovery from hypotension. If the increased release of catecholamine continues for a long period, peripheral circulation is compromised. Moreover, shock factors including that of myocardial depression will come into play because of the destruction of lysosomal membrane. ${ }^{13}$ It is speculated that in this situation, the administration of fluid and blood alone is not adequate for the treatment of haemorrhagic shock. Administration of large amounts of steroid combined with fluid and blood transfusion would decrease the over-secretion of catecholamines and $\mathrm{ADH}$, which results in improvement of the peripheral circulation, and protection of lysosomal membranes. ${ }^{14,15}$

\section{SUMMARY}

The effect of haemorrhage on endocrine function and the anti-shock effects of methylprednisolone were investigated in 32 mongrel dogs. Plasma concentrations of antidiuretic hormone (ADH), epinephrine, norepinephrine, aldosterone and cortisone were measured simultaneously during and following haemorrhagic hypotension. Other parameters, such as urine volume and osmolality, serum and urine electrolytes and blood glucose were also determined simultaneously during the procedure. Dogs anaesthetized with pentobarbitone were bled so that the mean arterial pressure decreased to $50 \mathrm{~mm} \mathrm{Hg}$, which was maintained for 15 minutes (group one) or for 30 minutes (groups two, three, and four). After the recovery of group one animals from the first hypotension by reinfusion of blood and hydroethylstarch, they were bled again to a mean arterial pressure of $50 \mathrm{~mm} \mathrm{Hg}$ (second hypotension) and were allowed to remain at this pressure. In groups two, three and four there was no second hypotension.

Plasma ADH concentrations were elevated 50 times control values on the first hypotension, but no appreciable increase was observed on the second hypotension. Plasma levels of epinephrine, norepinephrine and aldosterone increased 35,7 , and 5 times respectively during the first hypotension and 40,10 , and 5 times during the second hypotension, as compared to controls. Plasma osmolality correlated well with plasma $A D H$ levels during the haemorrhage. Increased concentrations of plasma $\mathrm{ADH}$, epinephrine and norepinephrine following haemorrhage had a tendency to decrease after the administration of fluids, but they were still higher than the preshack control levels. Methylprednisolone 15 $\mathrm{mg} / \mathrm{kg}$ or $30 \mathrm{mg} / \mathrm{kg}$ administered intravenously before infusion of blood and hydroethylstarch caused a significant decrease of plasma levels of ADH and epinephrine to pre-shock control levels. Our data suggest that the administration of methylprednisolone could be beneficial in improving the shock state from an endocrinological point of view.

\section{RÉSumé}

L'influence d'un choc hémorragique sur la 
fonction endocrinienne et l'effet antichoc de la méthylprednisolone ont été étudiés chez le chien. Trente-deux animaux formant quatre groupes ont été utilisés.

Nous avons mesuré pendant et après une hypotension par saignée les concentrations plasmatiques d'ADH, d'épinéphrine, de norépinéphrine, d'aldostérone et de cortisol, la glycémie, ainsi que le volume et l'osmolalité urinaire et, enfin, les électrolytes sériques et urinaires.

Après une anesthésie au pentobarbital, les chiens ont été saignés de façon à abaisser la pression moyenne à $50 \mathrm{~mm} \mathrm{Hg}$; cette pression a été maintenue 15 minutes chez les animaux du premier groupe, et $\mathbf{3 0}$ minutes chez ceux des trois derniers groupes. Après correction de l'hypotension au moyen de sang et d'une solution colloïdale ("hydroéthylstarch"), les animaux du premier groupe ont été saignés une deuxième fois jusqu'à ce que la pression moyenne redescende à $50 \mathrm{~mm}$, pression où ils ont été laissés. Après correction de leur hypotension, les animaux des trois derniers groupes n'ont pas été soumis à un deuxième épisode d'hypotension.

Le taux d'ADH plasmatique était 50 fois plus élevé que le taux des contrôles, au cours du premier épisode hypotensif, mais l'on n'a pas observé d'augmentation appréciable au cours du second épisode. Comparés aux contrôles, les niveaux plasmatiques d'épinéphrine, de norépinéphrine et d'aldostérone étaient respectivement 35 , sept et cinq fois plus grands au cours de la première hypotension et 40 , dix et cinq fois plus grands au cours de la seconde. Les modifications de l'osmolalité urinaire coincidaient avec celles de l'ADH. Les taux plasmatiques d'ADH, d'épinéphrine et de norépinéphrine élevés après la saignée, avaient tendance à diminuer après l'administration de volume, mais demeuraient plus élevés que les contrôles.

Une dose de 15 ou de $30 \mathrm{mg} /$ kilo de méthylprednisolone administrée par voie intraveineuse avant la correction liquidienne (sang + colloïdes) était suivie d'une diminution significative des taux d'ADH et d'épinéphrine jusqu'aux niveaux contrôles. Nos résultats suggèrent que le méthylprednisolone peut avoir des effets bénéfiques au point de vue hormonal dans le choc.

\section{REFERENCES}

1. Kudo, T., Kudo, M., \& Oyama, T. Radioimmunoassay of plasma vasopressin. Hormone and Clinics 24: 1311 (1976).

2. GrifFiths, J.C., LENNG, F.Y.T., \& MCDonald, T.J. Fluorimetric determination of plasma catecholamines: normal human epinephrine and norepinephrine levels. Clin. Chem. Acta 30: 395 (1970).

3. Mackenzie, J.K. \& Clements, J.A. Simplified radioimmunoassay for serum aldosterone utilizing increased antibody specificity. J. Clin. Endocr. Metab. 38:622 (1974)

4. Rudd, B.T., Sampson, P. \& Brook, B.N. A new fluorimetric method of plasma cortisol assay with a study of pituitary-adrenal function using metyrapone. Endocrinology 27: 317 (1963).

5. Shimamoto, K. \& Miyahara, M. Effect of norepinephrine infusion on plasma vasopressin levels in normal human subjects. J. Clin. Endocr. 43: 201 (1976).

6. Sachs, M., Share, L., Osinchak, J., \& Ca PRI, A Capacity of neurohypophysis to release vasopressin. Endocrinology 81: 755 (1968).

7. Lillehei, R.C., Longerbeam, J.K., Bloch J.H., \& MANAX, W.G. The nature of irreversible shock: experimental and clinical observations. Ann. Surg. 160: 682 (1964).

8. LeFer, A.M. \& Verriers, R.L. Role of corticosteroids in the treatment of circulatory collapse states. Clin. Pharmacol. Ther. 11:630 (1970).

9. Altura, B.M.\& Altura, B.T. Peripheral vascular actions of glucocorticoids and their relationship to protection in circulatory shock. J. Pharma. Exp. Therap. 190: 300 (1974).

10. KaLSNER, S. Mechanism of hydrocortisone potentation of responses to epinephrine and norepinephrine in rabbit aorta. Circ. Res. 24: 383 (1969).

11. HuGHEs, E. Evaluation of mechanisms controlling the release and inactivation of the adrenergic transmitter in the rabbit portal vein and vas deferens. Brit. J. Pharmacol. 44: 472 (1972).

12. Perry, L.B., Weinshilbaum, R.M., \& Theye, R.A. Plasma dopamine-beta-hydroxylase activity and catecholamine levels in anesthetized dogs following acute hemorrhage. Anesthesiology 43: 518 (1975).

13. LEFER, A.M. \& MARTIN, J. Studies on the origin of myocardial depressant factor in shock. Amer. J. Physiol. 213: 492 (1970).

14. GLENN, T.M. \& LAFEW, A.M. Anti-toxic action of methylprednisolone in hemorrhagic shock. Europ. J. Pharmacol. 13: 230 (1971).

15. Clermont, H.G., Williams, J.S., \& Adams, J.T. Steroid effect on the release of the lysosomal enzyme acid phosphatase in shock. Ann. Surg. 179: 917 (1974). 